Historic, Archive Document

Do not assume content reflects current scientific knowledge, policies, or practices. 





\section{FROST PROOF CABBAGE PLANTS}

(November to May)

CABBAGE PLANTS ALL THE YEAR

Early Jersey Wakefield, Charleston Wakefield, Flat Dutch, Succession Copenhagen Market, Danish Ballhead.

PARCEL POST PAID

50 for

100 for

300 for

500 for

1000 for

5000 and up at per 1000
F. O. B. SUMMERVILLE, S. C.

1000 to 4000 at. $\$ 1.00$ per 1000

5000 to 9000 at..................... .90 per 1000

10000 at 80 per 1000
$.75 \mathrm{c}$

1.00

.150
$.20 \mathrm{c}$

1.25

\section{TOMATO PLANTS}

(CERTIFIED)

Ready about March 20th and thereafter all Summer

EARLIANNA, STONE. RED ROCK, BONNIE BEST, CREATER BALTIMORE Price Same as Cabbage Plants.

Celery Plants: Giant Pascal, White Plume and Golden Self Blanching

Price Same as Tomato and Cabbage

Collard Plants-True Georgia, Cabbage Heading, and Fullmer BeET Plants - Early Blood Turnip LetTuce Plants--Big Boston, Iceburg, New York, Grand Rapids. ONION Plants-White Bermuda and Prizetaker BRUSSEL SPROUTS-L. I. Improved. KaLE PLANTs-Dwarf Green Curled Scotch KoHL-Robi Plants. Vienna Early White

All of the above are tied in bunches of 50, no less than 50 of any variety shipped. Early Snowball Cauliflower Plants are double the price of Cabbage plants.

Plants of same value can be assorted upon request, for instance 100 Cabbage, 100 Lettuce and 100 Onion Plants for $75 \mathrm{c}$.

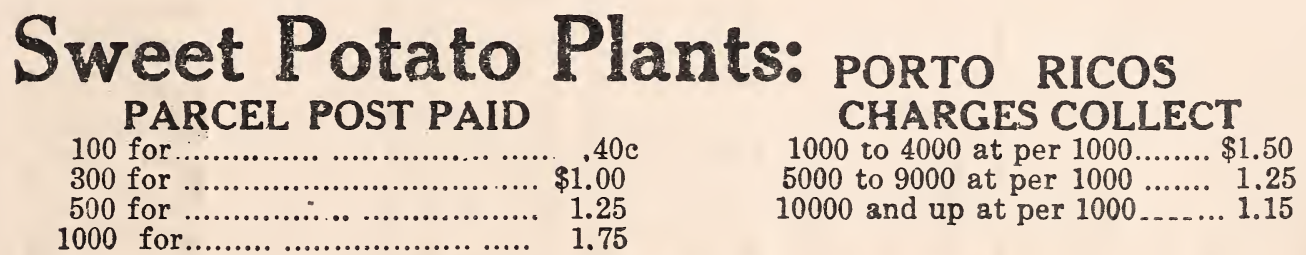

\section{- SEE OTHER SIDE -}


PEPPER PLANTS-Ruby King, Pimento and Tobasco. Egg PLANTS-N. Y. Improved.

(Ready about April 1st.)

These for convenience of small families are tied in $25 \mathrm{~s}$.

PARCEL POST PAID

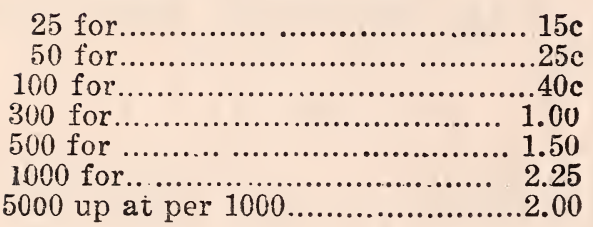

F. O. B. SumMERVILLE

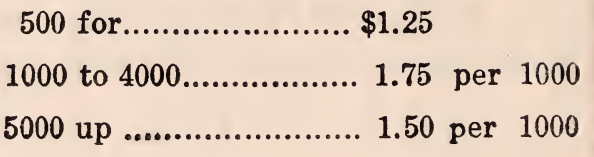

\section{FULL COUNT AND SAFE DELIVERY GUARANTEED}

Send Remittance With Order.

Nothing Sent C. O. D.

Reference:

BAMK OF DORCHESTER SUMMERVILLE, S. C. 